\title{
AGENT - NOWE KONTEKSTY UŻYCIA POJĘCIA W ZARZĄDZANIU PROJEKTAMI
}

DOI: $10.33141 /$ po.2020.08.03

Małgorzata Ćwikła
Przegląd Organizacji, Nr 8(967), 2020, s. 20-28

www.przegladorganizacji.pl

(c) Towarzystwo Naukowe Organizacji i Kierownictwa (TNOiK)

\section{Wprowadzenie}

W ostatnich dekadach pojawiło się wiele nowych zjawisk związanych $\mathrm{z}$ zarządzaniem projektami. Wystarczy wspomnieć chociażby o megaprojektach (Flyvbjerg, 2014), organizacjach tymczasowych (Lundin, Söderholm, 1995) i projektyzacji (Midler, 1995; Jałocha, 2019). Ograniczone harmonogramem, $z$ definicji elastyczne przedsięwzięcia o zadaniowym charakterze - jak ogólnie można określić projekty - okazały się optymalnym rozwiązaniem w dopasowywaniu trybów działania różnych organizacji do wymagań szybko zmieniającego się otoczenia. Przedsięwzięcia zbliżone do współczesnego rozumienia projektów obecne były już w cywilizacjach starożytnych, ale to właśnie XX wiek można uznać za renesans projektowego myślenia (Trocki, 2019). Na początku XXI wieku zaś stan projektowej fascynacji stał się status quo, doprowadzając do „projektyzacji wszystkiego" (Jensen i in., 2016) i uznania „społeczeństwa projektowego" za synonim „społeczeństwa wiedzy” (Lundin i in., 2015).

Prezentowany artykuł stanowi reakcję na inną, nową tendencję - coraz częstsze wplatanie w obrębie zarządzania projektami terminu „agent” w rozważania odbiegające od pierwotnego użycia wynikającego z popularnej teorii agencji. Zaobserwowano, że do dyskusji naukowych $\mathrm{o}$ agentach wprowadza się optykę związaną z działaniem, sprawczością, odpowiedzialnością, a nie tylko kontrolą czy hierarchią (Volden, Andersen, 2018). Ze względu na swobodę w posługiwaniu się wyrazami bliskoznacznymi przez badaczy (na przykład stosowanie wymiennie słowa „aktor” zamiast „agent”) w artykule uwzględniono dodatkowe terminy. Przeprowadzony przegląd literatury opiera się wyłącznie na źródłach anglojęzycznych z uwagi na fakt, że po angielsku "agent” często funkcjonuje w związku z pojęciem „agency” (sprawczość), co wprowadza interesujące punkty odniesienia. Właśnie to przesunięcie znaczeniowe, wykraczające poza relacje między agentem i pryncypałem uznano za warte poznania i najistotniejsze dla niniejszej analizy. Celem artykułu jest pokazanie stopniowej zmiany kontekstów, w których agent pojawia się w literaturze przedmiotu.

Artykuł ma charakter koncepcyjny i odnosi się do przeglądu literatury na temat aktualnego stanu wiedzy oraz wątków, które mogą być rozwinięte w przyszłości (state-of-the-art review, Grant, Booth, 2009). Impulsem do przygotowania przeglądu literatury była obecność określenia „agent” w dwóch publikacjach: Managing and Working in Project Society. Institutional Challanges of Temporary Organizations (Lundin i in., 2015) oraz Projectification of the Public Sector (Hodgson i in., 2019). Pojawia się w nich ono w różnych kontekstach, zastępując interesariuszy, organizatorów projektów oraz mediatorów zawartych $\mathrm{w}$ projektach znaczeń. W opracowaniach adresowani są „agenci projektów”, a także „agenci projektyzacji”. Obserwacja ta pozwoliła wysnuć przypuszczenie, że określenie „agent” jest obecnie przydatnym hasłem pozwalającym $\mathrm{w}$ nowatorski sposób przedstawiać projekty oraz mnożyć konteksty, w których są one realizowane, chociaż zauważono brak jednoznacznego omówienia, kim ten agent jest. Mimo popularności użycia terminu, kwestię bycia „agentem projektu" wciąż można uznawać zatem za temat nowy, dopiero rozwijany i zachęcający do podejmowania dalszych wysiłków poznawczych. Równocześnie chciano zareagować w odpowiednim momencie, zanim „agent” stanie się tak zwanym buzzword, dzieląc losy samego "projektu” w obszarze zarządzania, wyjątkowo podatnym na językowe mody i pustosłowie (Spicer, 2013). Zdecydowano się na tradycyjny przegląd literatury (Jesson i in., 2011) na podstawie kombinacji haseł „agent” oraz „project” albo „project management” szukanych w bazach Google Scholar, Emerald Insight oraz ProQuest Central. $\mathrm{Z}$ uwagi na dużą liczbę wyników oraz chęć pokazania aktualnych publikacji poszukiwanie zawężono do okresu 2010-2019 i, jeśli było to możliwe, do czasopism oraz książek naukowych. Nadal pojawiało się dużo publikacji: Google Scholar (1 350 000), ProQuest (177 798), Emerald Insight (ponad 17000 ), dlatego też pierwszych sto tekstów sprawdzono pod kątem obecności terminu agent $\mathrm{w}$ tytule i w słowach kluczowych.

Dobór przedmiotu badań kontynuowano, wybierając teksty z obszaru nauk o zarządzaniu, aby na podstawie stratyfikacji wyników zachować logikę całości i nie wprowadzać odległych perspektyw (Czakon, 2011). Po zebraniu pierwszej puli artykułów (łącznie: 131) przestudiowano ich abstrakty i wybrano 35 tekstów, których zakres tematyczny odpowiadał zarówno dyscyplinie, jak i problematyce, którą chciano zgłębić. Uzupełniająco zastosowano technikę kuli śnieżnej (Czakon, 2011), sprawdzając bibliografie wybranych źródeł i przechodząc do dalszych opracowań. W ten sposób dodano 8 artykułów, 
które nie miały określenia agent w tytule, słowach kluczowych i abstraktach, ale były wielokrotnie cytowane w innych źródłach. Uznano, że mogą one stanowić istotny element analizy, a ich nieobecność wśród wyników z wyszukiwarek stanowi przykład pominięcia ważnych tekstów przy tworzeniu przeglądów literatury (Lecy, Beatty, 2012). Dzięki temu możliwe było stworzenie mapy literatury dotyczącej agentów „w projektach” i „wokół projektów", a także zidentyfikowanie ujęć bliskoznacznych. Ostatecznie analiza oparta jest na 43 źródłach. Procedura metodologiczna umożliwiła koncentrację na tekstach bezpośrednio związanych $\mathrm{z}$ tematem, oddając ich różnorodność oraz pokazując potencjał rozwijania nowych kierunków badawczych w przyszłości, co uznano za istotne. Materiał zebrano samodzielnie i zapoznano się z nim w sposób tradycyjny, uważnie czytając i szukając dominujących wątków.

Na potrzeby badań sformułowano następujące pytania badawcze:

- PB1) W jakich kontekstach w literaturze przedmiotu używane jest określenie agent i czy jest ono jednoznacznie definiowane?

- PB2) Jakie alternatywne pojęcia obejmujące podobne cechy co agent pojawiają się w literaturze przedmiotu?

\section{Pojęcie agentów i sprawczości w naukach o zarządzaniu}

$\mathbf{P}$ odstawową kwestią dotyczącą sprawczości i wynikającego z niej pojęcia "agentów” - jako wykonawców określonych działań - jest relacja między jednostkami i grupami aktywnymi w danym otoczeniu organizacyjnym a organizacjami oraz między samymi agentami. W naukach o zarządzaniu jest to temat o fundamentalnym znaczeniu, dotyka on bowiem problemu wzajemnych zależności, które kształtują sens organizowania jako procesu zmierzającego do powstawania dóbr i usług, zarówno o wartości ekonomicznej, jak i symbolicznej. Figura agenta w zarządzaniu najczęściej łączona jest $\mathrm{z}$ teorią agencji, w której jest on zleceniobiorcą, wchodzącym w relacje z pryncypałem - zleceniodawcą. Rozwinęła się ona w efekcie dywersyfikacji grup mających wpływ na zarządzanie (Fox, Hamilton, 1994) jako przeciwieństwo teorii stewarda. Równocześnie agent jako byt łączony z pojęciem „sprawczości” (agen$c y)$, wprowadzony został do teorii zarządzania między innymi przez takich autorów, jak K. Eisenhardt (1989) czy A. Pettigrew i H. Willmott. Bazowali oni między innymi wybiórczo na strukturalistycznych teoriach A. Giddensa, podkreślając problematykę przywództwa oraz strategii (Whittington, 1992). Pozwoliło to na stworzenie punktu wyjścia dla innych autorów, głównie „instytucjonalistów”, skupiających się na relacjach z otoczeniem i wskazywaniu czynników oraz interesariuszy mających wpływ na procesy organizacyjne (DiMaggio, 1988; Lawrence i in., 2006; Maier, Simsa, 2020). Zarówno agent, jak i sprawczość to pojęcia analizowane zgodnie z podziałem na podejście deterministyczne, w którym kontekst wymusza pewne zachowania w organizacjach, oraz założenie woluntarystyczne, w którym istotniejsza jest wola jednostek i grup, odpowiadających na wymagania otoczenia w sposób świadomy i zgodny z własnymi potrzebami (Burrell, Morgan, 1979). Można więc uznać problem sprawczości za rozwinięcie potrzeby działania przez agenta i przejmowania odpowiedzialności, co w naukach o zarządzaniu nabrało znaczenia wraz z wygasaniem klasycznych teorii opartych na podejściu pozytywistycznym, obejmującym Taylorowski mechanizm ścisłego planowania i kontroli. Logiczne zatem byłoby szukanie źródeł charakteryzującej agenta sprawczości w szkole behawioralnej zarządzania, zwracającej uwagę na perspektywę pracowników, ich potrzeby i dążenia. Jak podkreślają T.B. Lawrence i inni (2006), skupiając się na relacjach między sprawcami danych czynności a tłem ich występowania, perspektywę należy wciąż poszerzać oraz pytać o chęci i faktyczny zakres wpływu jednostek i grup na organizacje i odwrotnie. Sprawczość, nawet bez bezpośredniego nawiązania do figury agenta, postrzegana też bywa jako efekt reagowania na bodźce, co może być rozumiane jako podejmowanie działań, czyli zarządzanie (Pindelski, 2012).

Problematyka agentów i sprawczości zanurzona jest w wielu kontekstach interpretacyjnych, których nie można pominąć. Uwzględnić tu trzeba między innymi wątki filozoficzne, w tym klasyczne pojęcie habitusu, które $\mathrm{w}$ toku dziejów ewoluowało $\mathrm{w}$ teoriach różnych myślicieli, ilustrując nie tylko zdolność do działania, ale także wolę. Próby przełożenia sprawczości i agenta na grunt zarządzania dokonują się również w przypadku „epistemologii praktyki”, w której wiedza uzupełniana jest przez doświadczenie, wspólnie warunkując możliwość działania (Raelin, 2017). Nurt ten aktualnie intensywnie się rozwija, inicjując dyskusje dotyczące nie tylko predyspozycji ludzkich, ale także nie-ludzkich, dostrzegając podmiotowość bytów, przedmiotów i zjawisk (Czarniawska, 2017). Podsumowując, ujęcie sprawczości jako możliwości, zdolności i chęci podejmowania akcji, choć $\mathrm{z}$ pozoru proste i będące alternatywnym sformułowaniem sensu zarządzania i organizowania jako procesów prakseologicznych, otwiera wiele ścieżek kognitywnych. Zawiera w sobie pytanie o kontrolę, komunikację, normy i reguły, twórczość oraz autonomię, a także zmianę (Pellegrinelli, Garagna, 2009) i współpracę - między innymi wywodzoną z francuskiego określenia agencement (Gherardi, 2016). Osią prezentowanego pojęcia nie jest więc precyzyjne definiowanie, co oznaczają „sprawczość” i „agent” w zarządzaniu projektami, ale szkicowanie tła dla tych określeń. Ich pojawienie się zaś często sygnalizuje próby zrozumienia zarządzania na nowo (Eikelan, Nicolini, 2011).

\section{Agent w rzeczywistości projektów}

$\mathrm{T}$ ermin agent oznaczający wykonawcę czynności kojarzy się ze zmienianiem jako celowo inicjowanym procesem, co $\mathrm{w}$ prostej linii odnosi się do zarządzania projektami. Tym samym - w podstawowym ujęciu - agent 
projektów to agent zmiany. W literaturze najczęstszym punktem odniesienia dla problematyki agentów w zarządzaniu projektami jest wspomniana teoria agencji, będąca jedną z teorii kontroli (Piotrowska, 2017). Jej sens stanowi regulowanie zależności między „pryncypałem” i zaangażowanym przez niego „agentem”, któremu zostaje powierzone dane zadanie. Wzajemne zobowiązania określone są kontraktem, co wprowadza nadrzędność pryncypała, stawiając agenta w sytuacji ciągłego nadzoru. Istotne jest zatem nie tylko zwrócenie uwagi na sprawczość poszczególnych stron, ale uwzględnienie ich indywidualnych dążeń, identyfikowanie ewentualnych zjawisk spornych i szukanie harmonii między interesami agenta i pryncypała, przede wszystkim zaś takie określenie odpowiedzialności, które umożliwi sensowny podział ryzyka (Turner, Müller, 2004; Shrestha i in., 2019). Zgodnie $z$ teorią agencji poszczególne zaangażowane $\mathrm{w}$ projekt strony są zainteresowane udaną współpracą i osiąganiem celów (Zwikael, Meredith, 2018; Derakhshan i in., 2019). Warto podkreślić, że pojęcie agenta w kontekście projektów rozwija się równolegle do innych tendencji $\mathrm{w}$ tym obszarze, na przykład coraz bardziej popularnych praktyk zwinnych nie tylko w nawiązaniu do pojedynczych projektów, ale również portfeli projektów i programów oraz dostrzegania potrzeby odświeżenia całego obszaru zarządzania projektami z uwagi na jego pogłębiającą się heterogeniczność i złożoność (Martinsou, Geraldi 2020). Tematy te funkcjonują w literaturze jako orientacja w kierunku uprawomocnienia (Kaufmann i in., 2020). Wnioskować zatem można, że istotne jest zwiększanie sprawczości, a "predyspozycje” agenta do bycia aktywnym mogą mieć doniosłe znaczenie również $\mathrm{w}$ zawiłych fenomenach organizacyjnych dokonujących się podczas zarządzania kilkoma projektami równocześnie (Sweetman, Conboy, 2018), skalowania projektów, a także w podejściach stawiających na nowatorstwo i zdolność do redefiniowania własnej roli w działaniu (Stettina, Hörz, 2015). Dotyczy to głównie konieczności wprowadzenia mechanizmów adaptacyjnych i rozumienia procesów projektowych i ich specyfiki napędzanej przez metodyki zwinne (Cooke-Davies i in., 2007), a także kwestii „odgrywania projektów” w obrębie ich grup (Blichfeldt, Eskerod, 2008) oraz w otoczeniu (Martinsou, Geraldi, 2020). Warto zatem podkreślić, że pojęcie agenta rozumieć trzeba szeroko i dostrzegać jego przystawalność do różnych nurtów zarządzania projektami. Pojawia się on zarówno, gdy mowa jest o możliwościach adaptacyjnych, samoorganizacji i autonomii, ale także w kontekście dążenia do precyzyjnego określenia pełnionej roli, w tym zakresu działania właściciela projektu i zespołu (co obejmuje zarówno ujęcia kaskadowe, jak i podejście scrum stanowiące część metodyk zwinnych). Obserwacja ta stanowi dodatkowy argument podkreślający doniosłość agentów i sprawczości nie tylko jako tematu rozważań, ale ciekawej ramy interpretacyjnej i metodologicznej (Nicolini, Monteiro, 2016; Gherardi, 2016).

W literaturze dotyczącej zarządzania projektami pojęcie agentów wykorzystywane jest mgliście, stąd trudność w sformułowaniu jednej, obowiązującej definicji. Dokonując przeglądu literatury, nie można więc dążyć do uproszczeń, tylko starać się pokazać różnorodność. Odnaleziono przykłady zastosowania omawianego terminu do określenia jednostek - menedżerów całych projektów albo wykonawców konkretnych zadań (Pellegrinelli, Garagna, 2009), lobbistów zabiegających o realizację projektów (Lundin i in., 2015), interesariuszy (Jacobsson, Söderholm, 2011), a także grup - rządów i innych instytucji politycznych (Godenhjelm i in., 2015). Mimo tego rozległego wachlarza ścieżek znaczeniowych, warto podjąć próbę oddzielenia agentów jako jednostek od agentów jako grup bądź całych organizacji. Podczas gdy w ujęciu jednostkowym chodzi o osoby, które nadają projektom sens organizacyjny i również społeczny albo z jakichś powodów są nimi zainteresowane, w drugim mowa jest o tworzeniu ram działania. Odmienne są kierunki - agenci jednostkowi skupiają się na projekcie i w efekcie muszą reagować na otoczenie, podczas gdy grupowi tworzą otoczenie zewnętrzne różnych organizacji i swoją uwagę w konkretnym momencie kierują na dany projekt. Wspomnieć należy także o ciągłości zaangażowania agentów. Agenci indywidualni pomiędzy projektami są w stanie „hibernacji” (Lundin i in., 2015), wracają do swoich rutynowych działań, czekając na nowy projekt, grupowi za to płynnie przechodzą od projektu do projektu, część z nich prowadząc zresztą równolegle $\mathrm{w}$ ramach ujęć programowych albo portfelowych.

Ciekawy przykład stanowi Unia Europejska uznawana za katalizator projektyzacji (Büttner, Leopold, 2016). Z jednej strony - jako całość - sama jest agentem instytucjonalnym projektów w procesie projektyzacji rzeczywistości, z drugiej opracowane przez nią procedury, których przestrzeganie konieczne jest $\mathrm{w}$ przypadku realizacji projektów ze źródeł Wspólnoty, wymaga zaangażowania indywidualnych albo innych grupowych agentów projektowych w niespotykanym zakresie. Są nimi nie tylko jednostki i organizacje zarządzające dofinansowanymi projektami, ale także pracownicy UE, którzy planują projekty oraz oceniają je po ich zakończeniu. Infrastruktura projektowa UE pozwala także na wprowadzanie $\mathrm{w}$ roli konsultantów czy doradców agentów zewnętrznych - ekspertów z danej dziedziny, innych menedżerów projektów (Jałocha, Ćwikła, 2019). Napędza to różnorodność, ale także ustanawia mechanizm kontroli. Grupowi agenci, jak UE, nie tylko więc zarządzają projektami, ale także inicjują je, kontrolują oraz ewaluują, a także tworzą i nadzorują całe zbiory projektów. Ponadto motywują do pracy w trybie projektowym, przyznając różnego rodzaju wsparcie. Agenci jednostkowi częściej łączeni są z wykonywaniem projektów - opracowywaniem konkretnych pomysłów i ich realizacją. Co zasygnalizowano wcześniej, można także rozumieć agentów projektów jako facylitatorów zmiany (Aubry i in., 2011; Tucker i in., 2015). W przypadku organizacji projektowych menedżer projektów powinien być agentem pozytywnej zmiany istotnej dla całej organizacji (Sundqvist, 2019). Agenci zmiany nie muszą formalnie wchodzić w skład zespołu projektowego, ale powinni towarzyszyć mu i wspierać procesy dokonujące się 
w trakcie rozwijania projektu, zaś w przypadku wieloletnich projektów inicjować mniejsze projekty zmierzające do zmiany rozumianej jako udoskonalanie procedur zarządzania projektami. P. Eskerod wraz ze współautorami (2017) przyjmuje za zasadne wybieranie agentów zmiany $\mathrm{z}$ tej samej organizacji. Dzięki temu proces wdrażania modyfikacji jest ułatwiony poprzez znajomość kultury organizacyjnej. W literaturze można znaleźć różne przykłady koncepcji opartych na agentach zmiany. Jedna $\mathrm{z}$ nich dotyczy podejmowania decyzji o włączeniu projektu do strategii (Mullaly, 2015).

W efekcie analizy literatury postawić można wniosek, że to kontekst nadaje uprawnienia agentom, co stanowi kontynuację wspomnianej wcześniej teorii instytucjonalnej, równocześnie jednak wprowadzając zależność między indywidualną sprawczością a otoczeniem oraz podkreślając kwestię przypisanej i odgrywanej „roli”. Patrząc holistycznie na problematykę, przywołać można inne badania, w których agenci są elementem kompleksowej koncepcji rozumienia zarządzania projektami. J. Söderlund (2011) wyodrębnił siedem szkół naukowych omawianej subdyscypliny, z których jedna oparta została między innymi na kryterium dostrzegania agentów projektów. Autor nazwał ją "governance school”, a zatem podkreślił kwestię dbania o ład. Cechy tego podejścia to hierarchia, kontrola, system biurokratyczny (Głodziński, 2019). Agenci są strażnikami porządku, ich rola jest tu przypisana odgórnie, a nie określana $\mathrm{w}$ dialogu (Söderlund, 2011). Agenci mają różną postać, wykonują wiele zadań i mogą być kojarzeni również ze zleceniodawcą danego projektu albo jego właścicielem (Andersen, 2012). Potwierdza się wcześniejsze przypuszczenie, że próba sformułowania jasnej definicji, kim jest agent projektów, jaki jest zakres jego sprawczości oraz pole działania, stanowi problem. Można odnieść wrażenie, że figura ta jest wykorzystywana poza kontekstem teorii agencji w reakcji na rozbudowywanie systemu projektowego i konieczność tworzenia filarów podtrzymujących go. W celu zachowania przejrzystości wywodu poniżej zestawiono pierwsze wnioski.

- AGENT PROJEKTÓW: jednostka lub grupa, działa wewnątrz danej organizacji albo w jej otoczeniu zewnętrznym, w obu przypadkach ma bezpośredni związek z danym projektem,

- CO ROBI: zmienia, zarządza, inicjuje, kontroluje, gwarantuje powodzenie, jeżeli działa we właściwym projekcie, odgrywa rolę przypisaną przez kontekst albo definiuje swoje miejsce w projekcie, doradza, działa na korzyść projektu, jest w grupie, wie dużo na temat projektu.

Trzeba też podkreślić, że omawiane określenie pojawia się jako synonim innych terminów.

\section{Między agentem, aktorem i członkiem kliki}

A utorzy M. Fred i D. Mukhtar-Lindgren (2019), podejmując dyskusję na temat agentów w kontekście projektyzacji sfery publicznej, wskazują na dwa wyjścio- we pytania: „kto?” oraz „jak?”. Interesują się więc doprecyzowaniem terminu oraz sprawdzeniem, w czym tkwi wyjątkowość i siła agentów. Podkreślają przy tym, że ich rozumienie odnosi się do pełnienia roli aktywnych mediatorów, zaangażowanych w proces zmian, kluczowy dla zarządzania projektami. Zasadne byłoby więc mówienie o wspomnianych już wcześniej agentach zmiany. Autorów nie satysfakcjonuje jednak generalizowanie. Ich zdaniem, mediatorzy mają swoją specyfikę i wyróżniają się byciem wewnątrz procesów dokonujących się w projektach (Fred, Mukhtar-Landgren, 2019). Podkreślają też, że inaczej jest $\mathrm{z}$ aktorami, którzy mogą być „poza” projektem. Na tej podstawie nasuwa się wniosek, że w obrębie grupy określeń zbliżonych do „agenta” funkcjonują drobne różnice, wskazujące na niuanse organizacyjne, związane z przypisaną rolą oraz miejscem w strukturze wytworzonej na potrzeby danego projektu.

Na początek warto dokładniej przyjrzeć się „aktorom” w zarządzaniu projektami, ponieważ ten termin pojawia się często, a także zauważalny jest trend naprzemiennego nazywania agentów aktorami projektów (Pemsel, Müller, 2012). Dotyczy to zwłaszcza uznania ich za interesariuszy (Lundin i in., 2015). Niektórzy autorzy wskazują, iż bliskoznaczne, a niekiedy traktowane jako synonimiczne wobec agentów pojęcie aktorów zaczęło pojawiać się $\mathrm{w}$ literaturze $\mathrm{z}$ zakresu zarządzania projektami w latach 90. XX wieku, towarzysząc innym propozycjom związanym z redefiniowaniem omawianej subdyscypliny. Dążenia te można łączyć z perspektywami krytycznymi i postmodernistycznymi, podkreślającymi procesowy charakter projektów, eksponującymi „wiedzę w działaniu”, "refleksję w działaniu” i epistemologie praktyczne (Lalonde i in., 2010). Zazwyczaj pisanie o „aktorze”, a nie tylko konsekwentnie o "agencie” to zabieg stylistyczny. Chodzi o unikanie powtórzeń i większą językową różnorodność. Warto jednak zauważyć, że samo intuicyjne rozumienie aktora odbiega od agenta. Aktor przypisany jest do konkretnej roli/zadania, podczas gdy agent to bardziej funkcja zawodowa, która może rozszerzać się poza granice danego projektu. Porównując agenta i aktora, dobrze odwołać się do etymologii tych słów. Oba terminy mają łacińskie pochodzenie od czasownika agere (działać, robić). Aktor łączony był w toku dziejów z oskarżycielem, wykonawcą na scenie, strażnikiem, agent natomiast $\mathrm{z}$ efektywnością, władzą, szpiegostwem (Online Etymology Dictionary, 2020). Wyczuwalne tu rozróżnienie znajduje odzwierciedlenie $\mathrm{w}$ literaturze, aktor bowiem kojarzony bywa $\mathrm{z}$ teorią praktyki (Blomquist i in., 2010), a zatem z podejmowaniem akcji, procesami, performatywnością, agent zaś $\mathrm{z}$ dbaniem o interesy, w tym o strategię (Löwstedt i in., 2018). Niejasne przy tym pozostaje, czy aktorzy wpisują się w kontekst starań konkurencyjnych, podczas gdy agenci raczej zainteresowani są współpracą. W tym duchu pojawiają się istotne wątki: „aktorzy krytyczni”, czyli interesariusze nie zawsze przekonani do projektu (Lundin i in., 2015), oraz prestiż, dostrzegany w wybranych rolach projektowych. G. Garel (2013) na przykład wspomina o architekcie gotyckiej katedry jako aktorze 
projektu oczekującym na najwyższe uznanie swoich osiągnięć, chociaż zarówno „menedżerem projektu”, jak i pracownikami wykonującymi zadania projektowe byli inni. Niektórzy z kolei piszą o aktywnej roli „właściciela projektu”, co skutkuje odpowiedzialnością (Andersen, 2012; Davis, 2014), ale nie musi oznaczać zaangażowania $\mathrm{w}$ prace projektowe. Podobnie zresztą jak w przypadku agenta, określenie aktor może dotyczyć jednostek, ale także grup, na przykład całego zespołu projektowego (Karlsen, 2010). Samymi aktorami w projekcie można zarządzać, a ich wyodrębnienie w procesach projektowych doprowadziło do instytucjonalizacji zarządzania projektami (Garel, 2013). Inicjuje to pytanie o sprawczość, które jednak w literaturze nie jest zadawane wprost. Wskazuje się wprawdzie na to, że sprawczość aktorów objawia się w swobodzie wybierania spośród różnych rozwiązań (Hällgren, Lindahl, 2017), co oznacza kompetencje decyzyjne $\mathrm{w}$ projekcie, wątek ten jednak nie dominuje $\mathrm{w}$ artykułach posługujących się hasłem „aktorzy”. Całokształt zjawisk projektowych, postrzeganych przez pryzmat działań aktorów, niektórzy autorzy uznają za „akt”. Takie podejście wymaga nowej orientacji naukowej, podkreślania czynnika ludzkiego, wprowadzania metodologii jakościowej, osadzonej w paradygmacie interpretatywnym (Lalonde i in., 2010; 2012).

Pojęcia aktor i agent można uznać za zbliżone, choć zdarza się, że każde z nich w innych sposób uwypukla specyfikę danej roli albo funkcji w działalności projektowej. Trudniejsze jest uchwycenie sensu rzadszych bliskoznacznych określeń. W literaturze na przykład zastępczo względem aktorów pojawiają się: gatekeepers - strażnicy, brokers - pośrednicy, clique members - członkowie kilki, fringe actors - aktorzy alternatywni (Müller i in., 2013). Nie są to jednak określenia opracowane metodologicznie i nie można uznać ich za hasła rozpoznawalne w dyscyplinie. Podobie z lobbistami i grupami nacisku - są oni nazywani aktorami albo agentami projektu, bez konsekwencji terminologicznej. Również na tym etapie warto podsumować dotychczasowe wnioski płynące $z$ analizy:

- SYNONIM / OKREŚLENIE BLISKOZNACZNE: aktor, mediator, strażnik, pośrednik, członek kliki, aktor alternatywny, lobbista, członek grup nacisku, interesariusz,

- CO ROBI: tłumaczy, pośredniczy, odgrywa rolę, działa w grupie/sieci, wykonuje zadanie, decyduje, krytykuje, czuje się częścią projektu.

\section{Agent projektów i powiązane zjawiska - dostrzegalne kierunki badawcze}

$\mathbf{P}$ rzyjęta procedura przeprowadzania przeglądu literatury, jak podkreślono na początku, odnosi się nie tylko do omówienia stanu wiedzy, ale również do identyfikacji nowych zjawisk. Na podstawie niniejszej analizy można stwierdzić, że na granicy refleksji o agentach pojawiają się alternatywne kierunki badawcze. Przede wszystkim zaś bogactwo stosowanych względem agenta synonimów bądź wyrazów bliskoznacznych pokazu- je, że termin ten nie jest już tylko częścią teorii agencji. W tym fragmencie nakreślone zostaną zauważone tematy, które sygnalizują nową orientację w obrębie zarządzania projektami i pojawiają się w artykułach dotyczących agentów. Na początek warto wrócić do wspomnianej już mediacji w zarządzaniu projektami. Jako czynność „mediacja” może dokonywać się w wielu kontekstach, ale niekiedy traktowana bywa jako rola wiodąca pracowników projektowych. Przywołani już autorzy - D. Mukhtar-Lindgren i M. Fred (2019) - rozwijają tę koncepcję w kilku tekstach. Na poziomie lokalnych polityk publicznych, będących pod wpływem polityki UE i stosowanych przez nią praktyk forsujących projekty, wskazują na mediatorów projektów jako osoby zaangażowane $\mathrm{w}$ proces translacji. Może on dotyczyć tłumaczenia procedur projektowych, a nawet wyjaśniania osobom zainteresowanym danym konkursem jego zakresu i wymagań. Nie chodzi przy tym o konkretne, pojedyncze projekty, ale ujęcie bardziej kompleksowe, w którym mediatorzy to zarówno eksperci unijni, urzędnicy lokalni, jak i naukowcy zmieniający podejście do projektów poprzez ich objaśnianie. Równocześnie trzeba podkreślić, że takie podejście koresponduje z problematyką wiedzy, dostępu do niej (Mukhtar-Landgren, Fred, 2019) i dzielenia się nią (Ding i in., 2014). Z uwagi na rozmyty charakter koncepcji mediatorów i mediacji w różnych tekstach trudno mówić o trwałym modelu znaczeniowym. Na uwagę zasługuje jednak wielość stosowanych w związku z nią perspektyw, w tym rozważań związanych $\mathrm{z}$ inteligencją emocjonalną (Zhang i in., 2017) oraz z nie-ludzkimi elementami „odpowiedzialnymi za mediację", a zatem sprawczymi w określonym zakresie. Może to być endogenny, czyli wynikający z dynamiki grupowej czynnik ładu korporacyjnego (Müller i in., 2016) albo sposób ujęcia zapisów w umowie między zleceniodawcą projektu i zleceniobiorcą (Ning, 2018). Pojawianie się tego typu kierunków, mających swój fundament $\mathrm{w}$ personifikowaniu procesów w obrębie zarządzania, pokazuje, że zarządzanie projektami otwarte jest na nowatorskie podejścia dotyczące sprawczości, mające swoje źródła w innych dyscyplinach. Nie jest to trop zupełnie nowy, bo kontynuuje tradycję Teorii Aktora-Sieci (Actor Network Theory - ANT), obecnej w literaturze z zakresu zarządzania projektami od końca XX wieku (Lundin i in., 2015). W ostatnich latach, w tle trwających dyskusji na temat automatyzacji, nabiera ona dodatkowego znaczenia, czego przykładem jest właśnie mediacja, a także mediatorzy. W literaturze dotyczącej zarządzania projektami ANT pojawia się jako punkt odniesienia dla procesów związanych z hierarchią (Aubry i in., 2010), badawcze narzędzie interpretacyjne (Blackburn, 2002), ale także jako metodologiczne i poznawcze poszerzanie zarządzania projektami o wątki znane z teorii społecznych (Floricel i in., 2014), w tym nadawanie sensu (Pollack i in., 2013) oraz uwzględnianie specyfiki badanego miejsca, co wymaga oryginalnej koncepcji epistemologicznej (Jensen, Sandström, 2020). Równocześnie nacisk kładziony jest na teorię praktyki jako punkt wyjścia dla rozpatrywania na nowo postulatów 
krytycznego nurtu zarządzania, w którym pogłębienia wymaga aspekt politycznej ontologii organizowania i działania (Alcadipani, Hassard, 2010). Ontologia zresztą to w przypadku nowych podejść dotyczących badania projektów płaszczyzna niebagatelna, koncentrująca się na „wykonawcach” zarządzania projektami i wplatana w refleksje znacznie młodsze niż ANT.

Inny, nowy trop dostrzegalny w przeanalizowanej literaturze to niedojrzała jeszcze koncepcja „enablers”, którą tłumaczy się zazwyczaj jako „warunki umożliwiające” - cechy, zjawiska, predyspozycje pomagające w wykonaniu danego zadania. W przypadku projektów R. Müller i współautorzy (2016), analizując pojęcie organizational enablers, pokazują rozumienie przenikające działania ludzkie ze zjawiskami, które wytwarzają się między członkami zespołu projektowego. Chociaż są to refleksje pionierskie, analiza kontekstów w literaturze, w której pojawia się agent projektów, budzi skojarzenia $\mathrm{z}$ rozwojem zjawisk związanych z podmiotowością, w tym technologiami generującymi zarówno przedmioty, jak i byty niematerialne, coraz częściej zdolne do przejmowania od ludzi różnych zadań, również w obszarze zarządzania (Wirtz i in., 2019). Co interesujące, w takim kompleksowym spojrzeniu, nawet same projekty mogą być uznane za agentów w obrębie portfeli projektów (Kaufmann i in., 2020). Tym samym „teoretyzowanie wokół” projektów wyznacza nową i intrygującą perspektywę na problematykę sprawczości w zarządzaniu.

Figura agenta projektu, łączona $\mathrm{z}$ jego chęcią i możliwością działania, zazwyczaj kojarzona bywa z aktywnością i predyspozycjami do osiągania celów. Równocześnie jednak trzeba pamiętać, że zarządzanie projektami nie jest wolne od niedoskonałości, co od blisko 20 lat podkreśla nurt krytyczny (Hodgson, Cicmil, 2016). Bliższe spojrzenie na agenta, postrzeganego jako osoba mająca wpływ na projekt, wprowadza nie tylko narrację podkreślającą potencjał jednostek, ale - paradoksalnie - pozwala także na dostrzeżenie ich ograniczeń. Dlatego ważny jest postulat redukowania oczekiwań wobec menedżerów projektów, co nie oznacza niwelowania zakresu ich sprawczości, ale tworzenie kultury, w której menedżerowie projektów nie muszą być „bohaterami” (Loufrani-Fedida, Missonier, 2015). Dzięki temu menedżer jako agent nie będzie tylko wykonawcą projektu, ale jego współtwórcą (Ika, Hodgson, 2014). Wprowadzanie agentów - jednostek, grup, zespołów projektowych albo całych instytucji - do omówień licznych problemów organizacyjnych to ciekawy etap w refleksji naukowej nad zarządzaniem projektami, ilustrujący testowanie nowych kierunków oraz podejść w rozumieniu praktyki organizacyjnej. Proces ten wciąż trwa.

\section{Podsumowanie}

$\mathbf{P}$ rzeprowadzona analiza w odniesieniu do PB1 (W jakich kontekstach w literaturze przedmiotu używane jest określenie agent i czy jest ono jednoznacznie definiowane?) pokazuje, że pojęcie „agenta” w nauce o zarządzaniu projektami ulega obecnie semantycznemu poszerzeniu od pierwotnego ujęcia inspirowanego teorią agencji po liczne odniesienia mniej precyzyjne, związane z odgrywaniem różnych "ról” w projektach i w związku z nimi. Wprowadza to ryzyko ograniczenia precyzji terminu, równocześnie też warunkuje konieczność uchwycenia znaczeń i dokumentowania toku myślenia badaczy zajmujących się zarządzaniem projektami, którzy szukają w języku określeń odpowiednich do nazwania nowych zjawisk organizacyjnych. Agenci zmieniają poprzez projekty, ale także inicjują je, kontrolują, oceniają, prowadzą i wspierają innych w zadaniach projektowych. Agentami mogą być jednostki, ale także organizacje. O agentach mówi się w przypadku pojedynczych projektów, a także programów oraz portfeli. Punkt odniesienia stanowią metodyki tradycyjne oraz zwinne. Jednoznaczna definicja agenta projektów oraz wykonywanych przez niego ról mimo zastosowania we wspomnianych kontekstach nie została znaleziona w literaturze, co stanowi lukę badawczą. W nawiązaniu do PB2 (Jakie alternatywne pojęcia obejmujące podobne cechy co agent pojawiają się w literaturze przedmiotu?) warto dostrzec, że występują różne określenia bliskoznaczne, często traktowane jako synonimy. Udało się znaleźć między innymi aktorów, mediatorów, członków kliki, pośredników. Lukę badawczą stanowi brak jednoznacznego określenia każdego $\mathrm{z}$ nich, co sprawia, że w literaturze występuje terminologiczna niekonsekwencja. Opracowanie wskazanych haseł i osadzenie ich w interdyscyplinarnym kontekście uwzględniającym wszystkie niuanse, podobieństwa i różnice mogłoby stanowić istotny wkład w rozwój nauk o zarządzaniu.

Popularność agenta zarówno w teorii agencji, jak i w nowych podejściach do projektów można uznać za efekt mnożących się dyskusji dotyczących nauk o zarządzaniu w ostatnich dekadach, których celem jest modernizacja, a także dostosowanie do wyzwań niepewnej przyszłości. Równocześnie omawiane zjawisko pokazuje, że z uwagi na przyrost prac i podejść badawczych do projektów pojawiała się konieczność usystematyzowania metodologii, wiedzy coraz częściej grupowanej w szkoły zarządzania projektami oraz terminologii. Warto pamiętać, że określenie agent wpisało się w dyskurs naukowy, ale nie funkcjonuje w języku praktyków i nie musi być przez nich uświadomione (Joslin, Müller, 2016). Zarazem reprodukowanie roli agenta (oraz określeń zbliżonych) w literaturze nadaje sens nowemu spojrzeniu na jednostki i grupy w organizacjach oraz przedsięwzięciach jednorazowych.

Niniejsza analiza może przyczynić się do udoskonalania polskiego piśmiennictwa w omawianym obszarze poprzez uczulanie na kwestie językowe i zachowywanie precyzji w posługiwaniu się nowymi terminami, a także odczytywanie sygnałów związanych z przyszłością refleksji o zarządzaniu projektami. Podstawowym wnioskiem z przeprowadzonego przeglądu literatury jest stwierdzenie, że mimo drobnych rozbieżności i braku jednej konwencjonalnej definicji, agent $\mathrm{w}$ zarządzaniu projektami to figura, która może być uznana za przejaw alternatywnej klasyfikacji projektów, w której liczą się 
otoczenie, zdolności, kompetencje oraz nastawienie na aktywność dążących do celu grup i jednostek. Tym samym sens mówienia o agentach stanowi powrót do źródeł zarządzania projektami z ich elastycznością, kreatywnością, przy czym wymaga refleksyjności i dostrzegania mocy sprawczej w kontekście praktyki, a także wpływu procesów dokonujących się na zewnątrz i wewnątrz projektów (Toivonen, Toivonen, 2014). Na koniec warto dodać, że pojęcie agentów nie jest wolne od patologii występujących w organizowaniu. Mimo podkreślania osadzonych w filozoficznej tradycji tez o sprawczości i pozytywnych stronach podejmowania działań, agenci łączeni są z rozbudowywaniem systemu kontroli, konkurencją oraz rywalizacją wynikającą z dbałości o własne interesy. Agent to zatem hasło równie pojemne, co ambiwalentne i wciąż szukające tożsamości naukowej. Zasadne byłoby sprawdzenie za kilka lat w literaturze dotyczącej zarządzania projektami, w jakich kontekstach się ono pojawia, co stanowiłoby uzupełnienie tego opracowania, a także zweryfikowałoby dalszy los zasygnalizowanych tu potencjalnych kierunków badań.

\section{dr Małgorzata Ćwikła \\ Uniwersytet Jagielloński \\ Wydział Zarządzania i Komunikacji Społecznej \\ ORCID: 0000-0003-3724-7296 \\ e-mail: malgorzata.cwikla@uj.edu.pl}

\section{Bibliografia}

[1] Alcadipani R., Hassard J. (2010), Actor-Network Theory, Organizations and Critique: Towards a Politics of Organizing, „Organization," Vol. 17, No. 4, pp. 419-435.

[2] Andersen E.S. (2012), Illuminating the Role of the Project Owner, „International Journal of Managing Projects in Business", Vol. 5 No. 1, pp. 67-85.

[3] Aubry M., Hobbs B., Müller R., Blomquist T. (2010), Identifying Forces Driving PMO Changes, „Project Management Journal", Vol. 41, pp. 30-45.

[4] Blackburn S. (2002), The Project Manager and the Project-network, „International Journal of Project Management”, Vol. 20, No. 3, pp. 199-204.

[5] Blichfeldt B., Eskerod P. (2008), Project Portfolio Management - There's More To it Than What Management Enacts, „International Journal of Project Management”, Vol. 26, No. 4, pp. 357-365.

[6] Blomquist T., Hällgren M., Nilsson A., Söderholm A. (2010), Project-as-Practice: In Search of Project Management Research that Matters, „Project Management Journal”, Vol. 41, No. 1, pp. 5-16.

[7] Burrell G., Morgan G. (1979), Sociological Paradigms and Organisational Analysis: Elements of the Sociology of Corporate Life, Ashgate Publishing Limited, Farnham.

[8] Büttner S.M., Leopold L.M. (2016), A 'New Spirit' of Public Policy? The Project World of EU Funding, „European Journal of Cultural and Political Sociology", Vol. 3, No. 1, pp. $41-71$.
[9] Cooke-Davies T., Cicmil S., Crawford L., Richardson K. (2007), We're not in Kansas Anymore, Toto: Mapping the Strange Landscape of Complexity Theory, and its Relationship to Project Management, „Project Management Journal", Vol. 38, No. 2, pp. 50-61.

[10] Czakon W. (2011), Metodyka systematycznego przegladu literatury, „Przegląd Organizacji”, Nr 3, s. 57-61.

[11] Czarniawska B. (2017), Bruno Latour and Niklas Luhmann as Organization Theorists, „Eureopan Management Journal”, Vol. 35, pp. 145-150.

[12] Davis K. (2014), Different Stakeholder Groups and their Perceptions of Project Success, „International Journal of Project Management”, Vol. 32, No. 2, pp. 189-201.

[13] Derakhshan R., Turner R., Mancini M. (2019), Project Governance and Stakeholders: A Literature Review, „International Journal of Project Management”, Vol. 37, No. 1, pp. 98-116.

[14] DiMaggio P.J. (1988), Interest and Agency in Institutional Theory, [in:] L.G. Zucker (ed.), Institutional Patterns and Organizations, Ballinger, Cambridge, pp. 3-21.

[15] Ding Z., Ng F., Li J. (2014), A Parallel Multiple Mediator Model of Knowledge Sharing in Architectural Design Project Teams, „International Journal of Project Management", Vol. 32, No. 1, pp. 54-65.

[16] Eikelan O., Nicolini D. (2011), Turning Practically: Broadening the Horizon, „Journal of Organizational Change", Vol. 24, No. 2, pp. 164-174.

[17] Eisenhardt K. (1989), Agency Theory: An Assessment and Review, „Academy of Management Review”, Vol. 14, No. 1, pp. 57-74.

[18] Eskerod P., Justesen J.B., Sjøgaard G. (2017), Enriching Project Organizations with Formal Change Agents: Health Promotion Projects at the Workplace, "International Journal of Managing Projects in Business", Vol. 10, No. 3, pp. 578-599.

[19] Floricel S., Bonneau C., Aubry M., Sergi V. (2014), Extending Project Management Research: Insights from Social Theories, „International Journal of Project Management”, Vol. 32, No. 7, pp. 1091-1107.

[20] Flyvbjerg B. (2014), What You Should Know about Megaprojects and Why: An Overview, „Project Management Journal”, Vol. 45, No. 2, pp. 6-19.

[21] Fox M.A., Hamilton R.T. (1994), Ownership and Diversification: Agency Theory or Steward Theory, „Journal of Management Studies", Vol. 31, pp. 69-81.

[22] Fred M., Mukhtar-Landgren D. (2019), Agents, Techniques, and Tools of Projectification, [in:] D. Hodgson, M. Fred, S. Bailey, P. Hall (eds.), The Projectification of the Public Sector, Routledge, New York, pp. 189-208.

[23] Garel G. (2013), A History of Project Management Models: From Pre-models to the Standard Models, „International Journal of Project Management”, Vol. 31, No. 5, pp. 663-669.

[24] Gherardi S. (2016), To Start Practice Theorizing Anew: The Contribution of the Concepts of Agencement and Formativeness, „Organization”, Vol. 23, No. 5, pp. 680-698.

[25] Głodziński E. (2019), Project governance - istota, dotychczasowe kierunki badawcze i perspektywy rozwoju, „Przegląd Organizacji”, Nr 3, s. 32-42. 
[26] Godenhjelm S., Lundin R.A., Sjöblom S. (2015), Projectification in the Public Sector - The Case of the European Union, „International Journal of Managing Projects in Business", Vol. 8, No. 2, pp. 324-348

[27] Grant M.J., Booth A. (2009), A Typology of Reviews: An Analysis of 14 Review Types Andassociated Methodologies, „Health Information and Libraries Journal”, Vol. 26, pp. 91-108.

[28] Hällgren M., Lindahl M. (2017), Coping with Lack of Authority: Extending Research Onproject Governance with a Practice Approach, „International Journal of Managing Projects in Business", Vol. 10, No. 2, pp. 244-262.

[29] Hodgson D., Cicmil S. (2016), Making Projects Critical 15 Years on: A Retrospective Reflection (2001-2016), „International Journal of Managing Projects in Business", Vol. 9, No. 4, pp. 744-751.

[30] Hodgson D., Fred M., Bailey S., Hall P. (eds.), (2019), The Projectification of the Public Sector, Routledge, New York.

[31] Ika L.A., Hodgson D. (2014), Learning from International Development Projects: Blending Critical Project Studies and Critical Development Studies, „International Journal of Project Management”, Vol. 32, No. 7, pp. 1182-1196.

[32] Jacobsson M., Söderholm A. (2011), Breaking Out of the Straitjacket of Project Research: In Search of Contribution, "International Journal of Managing Projects in Business", Vol. 4, No. 3, pp. 378-388.

[33] Jałocha B. (2019), Projektyzacja jako przedmiot badań w ramach studiów nad projektami, „Przegląd Organizacji”, Nr 8, s. 34-41.

[34] Jałocha B., Ćwikła M. (2019), Observing the Process of Culture Projectification and its Agents: A Case Study of Kraków, [in:] D. Hodgson, M. Fred, S. Bailey, P. Hall (eds.), The Projectification of the Public Sector, Routledge, New York, pp. 209-228.

[35] Jensen T., Sandström J. (2020), Organizing Rocks: ActorNetwork Theory and Space, „Organization”, Vol. 27, No. 5, pp. 701-716.

[36] Jensen A., Thuesen C., Geraldi J. (2016), The Projectification of Everything: Projects as a Human Condition, „Project Management Journal”, Vol. 47, No. 3, pp. 21-34.

[37] Jesson J., Matheson L., Lacey F.M. (2011), Doing Your Literature Review. Traditional and Systematic Techniques, SAGE, London.

[38] Joslin R., Müller R. (2016), Identifying Interesting Project Phenomena Using Philosophical and Methodological Triangulation, „International Journal of Project Management", Vol. 34, No. 6, pp. 1043-1056.

[39] Karlsen J.T. (2010), Project Owner Involvement for Information and Knowledge Sharing in Uncertainty Management, „International Journal of Managing Projects in Business", Vol. 3, No. 4, pp. 642-660.

[40] Kaufmann C., Kock A., Gemünden H.G. (2020), Emerging Strategy Regcognition in Agile Portfolios, „International Journal of Project Management”, Vol. 38, No. 7, pp. 429-440.

[41] Lalonde P.-L., Bourgault M., Findeli A. (2012), An Empirical Investigation of the Project Situation: PM Practice as an Inquiry Process, „International Journal of Project Management”, Vol. 30, No. 4, pp. 418-431.
[42] Lalonde P.-L., Bourgault M., Findeli A. (2010), Building Pragmatist Theories of PM Practice: Theorizing the Act of Project Management, „Project Management Journal”, Vol. 41, No. 5, pp. 21-36.

[43] Lawrence T.B., Suddaby R., Leca B. (2006), Introduction: Theorizing and Studying Institutional Work, [in:] T.B. Lawrence, R. Suddaby, B. Leca (eds.), Institutional Work: Actors and Agency in Institutional Studies of Organizations, Cambridge University Press, Cambridge, pp. 1-27.

[44] Lecy J., Beatty K.E. (2012), Representative Literature Reviews Using Constrained Snowball Sampling and Citation Network Analysis, https://ssrn.com/abstract=1992601 or http://dx.doi.org/10.2139/ssrn.1992601, access date: 30.05 .2020 .

[45] Loufrani-Fedida S., Missonier S. (2015), The Project Manager Cannot Be a Hero Anymore! Understanding Critical Competencies in Project-based Organizations from a Multilevel Approach, „International Journal of Project Management", Vol. 33, No. 6, pp. 1220-1235.

[46] Löwstedt M., Räisänen Ch., Leiringer R. (2018), Doing Strategy in Project-based Organizations: Actors and Patterns of Action, „International Journal of Project Management", Vol. 36, No. 6, pp. 889-898.

[47] Lundin R., Arvidsson N., Brady T., Ekstedt E., Midler Ch., Sydow J. (2015), Managing and Working in Project Society: Institutional Challenges of Temporary Organizations, Cambridge University Press, Cambridge.

[48] Lundin R., Söderholm A. (1995), A Theory of the Temporary Organization, „Scandinavian Journal of Management", Vol. 11, No. 4, pp. 437-455.

[49] Maier F., Simsa R. (2020), How Actors Move from Primary Agency to Institutional Agency: A Conceptual Framework and Empirical Application, „Organization”, https://journals. sagepub.com/doi/full/10.1177/1350508420910574\#articleCitationDownloadContainer, access date: 07.05.2020.

[50] Martinsou M., Geraldi J. (2020), Management of Project Portfolios: Relationships of Project Portfolios with their Contexts, „International Journal of Project Management”, Vol. 38, No. 7, pp. 441-453.

[51] Midler Ch. (1995), Projectification of the Firm - The Renault Case, "Scandinavian Journal of Management”, Vol. 11, No. 4, pp. 363-375.

[52] Mukhtar-Landgren D., Fred M. (2019), Re-compartmentalizing Local Policies? The Translation and Mediation of European Structural Funds in Sweden, „Critical Policy Studies", Vol. 13, No. 4, pp. 488-506.

[53] Mullaly M. (2015), Exercising Agency. Decision Making and Project Initiation, Routledge, New York.

[54] Müller R., Glückler J., Aubry M., Shao J. (2013), Project Management Knowledge Flows in Networks of Project Managers and Project Management Offices: A Case Study in the Pharmaceutical Industry, „Project Management Journal", Vol. 44, No. 2, pp. 4-19.

[55] Müller R., Shao J., Pemsel S. (2016), Organizational Enablers for Project Governance, Project Management Institute, Newtown Square.

[56] Nicolini D., Monteiro, P. (2016), The Practice Approach: For a Praxeology of Organizational and Management Studies, 
[in] A. Langley, H. Tsoukas (eds.), The SAGE Handbook of Process Organization Studies. Business \& Management, Sage, London, pp. 110-126.

[57] Ning Y. (2018), Impact of Quality Performance Ambiguity on Contractor's Opportunistic Behaviors in Person-to-organization Projects: The Mediating Roles of Contract Design and Application, „International Journal of Project Management", Vol. 36, No. 4, pp. 640-649.

[58] Online Etymology Dictionary, https://www.etymonline. com, access date: 05.06.2020.

[59] Pellegrinelli S., Garagna L. (2009), Towards a Conceptualisation of PMOs as Agents and Subjects of Change and Renewal, „International Journal of Project Management”, Vol. 27, No. 7, pp. 649-656.

[60] Pemsel S., Müller R. (2012), The Governance of Knowledge in Project-based Organizations, „International Journal of Project Management", Vol. 30, No. 8, pp. 865-876.

[61] Pindelski M. (2012), Paradygmaty holistycznego wariablizmu oraz sprawczości w naukach o zarządzaniu, „Organizacja i Kierowanie", Nr 2, s. 23-32.

[62] Piotrowska A. (2017), Zastosowanie teorii agencji $w$ zarządzaniu, „Przegląd Nauk Ekonomicznych”, Nr 25, s. 11-19.

[63] Pollack J., Costello K., Snakaran S. (2013), Applying Actor-Network Theory as a Sensemaking Framework for Complex Organisational Change Programs, „International Journal of Project Management", Vol. 31, No. 8, pp. 1118-1128.

[64] Raelin J.A. (2017), Toward an Epistemology of Practi$c e$, „Academy of Management Learning and Education”, Vol. 6, No. 4, pp. 495-519.

[65] Shrestha A., Tamošaitienè J., Martek I., Hosseini M.R., Edwards D.J. (2019), A Principal-Agent Theory Perspective on PPP Risk Allocation, „Sustainability”, Vol. 11(22), 6455, pp. 1-18, https://www.mdpi.com/2071-1050/11/22/6455, access date: 13.03.2020.

[66] Söderlund J. (2011), Pluralism in Project Management: Navigating the Crossroads of Specialization and Fragmentation, „International Journal of Management Reviews”, Vol. 13, No. 2, pp. 153-176.

[67] Spicer A. (2013), Shooting the Shit: The Role of Bullshit in Organisations, „M@n@gement”, Vol. 16, No. 5, pp. 653-666.

[68] Stettina C., Hörz J. (2015), Agile Portfolio Management: An Empirical Perspective on the Practice in Use, „International Journal of Project Management", Vol. 33, No. 1, pp. 140-152.

[69] Sundqvist E. (2019), The Role of Project Managers as Improvement Agents in Project-Based Organizations, „Project Management Journal”, Vol. 50, No. 3, pp. 376-390.

[70] Sweetman R., Conboy K. (2018), Portfolios of Agile Projects, „Project Management Journal”, Vol. 49, No. 6, pp. 18-38.

[71] Toivonen A., Toivonen P.U. (2014), The Transformative Effect of Top Management Governance Choices on Project Team Identity and Relationship with the Organization - An Agency and Stewardship Approach, „International Journal of Project Management", Vol. 32, No. 8, pp. $1358-1370$
[72] Trocki M. (2019), Podejścia badawcze w zarządzaniu projektami - geneza i ewolucja, „Przegląd Organizacji”, Nr 3, s. 3-9.

[73] Tucker J., Hendy J., Barlow J. (2015), The Importance of Role Sending in the Sensemaking of Change Agent Roles, „Journal of Health Organization and Management", Vol. 29, No. 7, pp. 1047-1064.

[74] Turner J.R., Müller R. (2004), Communication and Cooperation on Projects between the Project Owner as Principal and the Project Manager as Agent, „European Management Journal", Vol. 21, No. 3, pp. 327-336.

[75] Volden G.H., Andersen B. (2018), The Hierarchy of Public Project Governance Frameworks: An Empirical Study of Principles and Practices in Norwegian Ministries and Agencies, „International Journal of Managing Projects in Business", Vol. 11, No. 1, pp. 174-197.

[76] Wen Q., Qiang M. (2016), Enablers for Organizational Project Management in the Chinese Context, „Project Management Journal", Vol. 47, No. 1, pp. 113-126.

[77] Whittington R. (1992), Putting Giddens into Action: Social Systems and Managerial Agency, "Journal of Management Studies", Vol. 29, No. 6, pp. 693-712.

[78] Wirtz B.W., Weyerer J.C., Geyer C. (2019), Artificial Intelligence and the Public Sector - Applications and Challenges, „International Journal of Public Administration”, Vol. 42, No. 7, pp. 596-615.

[79] Zhang L., Cao T., Wang Y. (2017), The Mediation Role of Leadership Styles in Integrated Project Collaboration: An Emotional Intelligence Perspective, „International Journal of Project Management", Vol. 36, No. 2, pp. 317-330.

[80] Zwikael O., Meredith J.R. (2018), Who's Who in the Project Zoo? The Ten Core Project Roles, „International Journal of Operations \& Production Management”, Vol. 38, No. 2, pp. 474-492.

\section{Agent - New Context for Using the Concept in Project Management}

\section{Summary}

In recent years, the English language literature on project management mentions the term "agent" in brand-new contexts that go beyond the agency theory with which is typically associated. The purpose of the paper is to present areas of deliberation in which agent appears in connection with the concept of agency, role playing, task performance, and also mediation and translation in projects. Attention is also paid to the commonly used terms synonymous with agent such as actor or mediator. Based on the literature review the necessity of precise terminology concerning agents and agency in project management has been outlined and the research gaps have been showed. The approach focused on agents emphasises among others the perspective of non-humans in management.

\section{Keywords}

agent, agency in project management, agency theory, project management 